\title{
The Interaction Between Contract and Competition Law
}

\author{
Draft Paper: Under Revision \\ Prepared for the \\ $20^{\text {th }}$ Pacific Trade and Development Conference \\ Competition in the New Millenium \\ September 16-18, 2002 \\ Makati, Metro Manila, Philipines
}

by

Lewis Evans and Neil Quigley

http://www.iscr.org.nz

Acknowledgement: Input of Garry Goddard is gratefully acknowledged 


\section{Introduction}

This paper provides some economic perspectives on the interaction between contract law and competition (antitrust) law. First, it surveys some relevant aspects of the literature and provides some specific examples relating to:

(i) The theory and development of contract enforcement institutions,

(ii) Vertical contractual relationships between firms at different levels in the production and supply chain; and

(iii) The role of contracts in enabling specialised investments to take place by limiting opportunism, spreading risks and assigning property rights.

Second, it considers the lessons that developing countries may draw from this literature as they consider the sequencing of reforms relating to contract and competition law, and the economic implications of the commitment of resources to developing Western-style legal frameworks in each area of law.

Most contractual relationships raise questions about the balance between the efficiency gains from ex ante specification of rights and entitlements, and the potential reduction in social welfare that may come from the exclusion of other parties from the relationship and the resources committed to it. By focusing only on the detriment side of the welfare ledger, especially where the resources committed or the market shares of the contracting parties are large in the context of the relevant markets, enforcement of competition law may sometimes reduce welfare by overturning or undermining contracts that have large efficiency benefits but nonetheless may have some lesser anti-competitive detriment. Further, setting aside contracts on anti-competitive grounds that have been on foot for a significant term, due to changed circumstances that were unforeseen at the time of contracting, imposes external costs on the wider economy.

The paper proceeds as follows:

- Section 2 considers the role of contracts and the need for their enforcement. 
- Section 3 examines the theory and history of enforceability and its intersection with competition law

- Section 4 looks at the choice between vertical integration, contracts and spot markets as substitute vertical control instruments for firms.

- Section 5 draws on the economics literature to consider how contracts can impact competition, and how competition law can distort managerial choice between contracts and vertical integration.

- Section 6 examines the economic benefits associated with long-term contracting and looks at how these types of contracts are dealt with by Australian and New Zealand competition law, particularly the authorisation procedures.

- Section 7 looks in more detail at two New Zealand examples (the Kapuni and Telecom/Clear cases) where contract law and competition law have interacted.

- Section 8 concludes by arguing that the balance between contract and competition law in Western economies may not be correct, that competition law in these economies may be inhibiting the use of some types of efficient contractual relationships, and that to maximise economic efficiency developing economies should focus on the development of a framework for the enforcement of contracts first and consider competition law as a second propriety.

\section{Contracts and Enforcement}

The ability to write and enforce contracts promotes economic efficiency and enhances social welfare. In particular, long-term contracts of the type required to underpin large investments or facilitate access to network industries are important for driving dynamic efficiency.

Contracts necessarily impose restrictions on the actions of parties through the terms and conditions of the contract. From an economics perspective, contracts enable certain market arrangements to be put in place and certain investments to take place that otherwise would not be possible, by providing a degree of certainty about the obligations and conduct of the parties to the contract. They do this by: 
- Limiting the potential for opportunistic behaviour;

- Reducing the transactions costs of organising economic activity (by holistically addressing a range of issues simultaneously and providing a means of enforcement); and

- Assigning property rights and

- Allocating risks between the parties to the contract.

Contracts are forward looking arrangements that parties believe will maximise their net benefits ex ante in the presence of uncertainty about the future state of the world. One or more parties to a contract may take a different view ex post and perhaps seek to either have the contract renegotiated, or unilaterally breach the contract, or have the contract invalidated through legal channels. One legal avenue is to claim that the contract is in breach of competition law. ${ }^{1}$

As we discuss below, competition law tends to view contracts and other restrictions on the behaviour of economic entities with some suspicion. This is especially the case with the example of exclusive contracts that effect vertical relationships between firms, and relationship-specific contracts which are long-term in nature. Contracts found to be in breach of the law may be declared void, and be unenforceable. The whole contract may be affected, or in some cases, the provisions tainted by illegality may be severed, preserving the enforceability of the other provisions. ${ }^{2}$

Where contracts cannot be enforced ex post and the associated property rights under the contract are re-assigned or invalidated, the certainty required to underpin future investments is undermined and this may have implications for a party's willingness to commit to investments requiring enforceable contracts in the future. If the enforceability of contracts is reduced they will be used less often in the future or be more costly to put in place in the future. Either way, investment is reduced, and society is worse off. Competition Law”, World Competition, Vol. 23, pp. 79-94.

Section 89 of New Zealand's Commerce Act deals with the issue of severance providing that "the fact that a contract contains a provision which was entered into in breach of section 27, or giving effect to which would breach section 27, does not affect the enforceability of any other provision of the contract ..." As noted by Evans and Quigley, ibid, it may be inefficient to set aside only part of the bundle of obligations agreed to under a contract (see pp. 86-87). 
For contracts to be effective it is important that they are enforceable. As we have noted in an earlier paper: "From the perspective of economics, all provisions of legal contracts should be enforced irrespective of the ex post facto distribution of gains associated with completion of the contract, and the maxim is applicable to all market situations.”3 Yet some contracts may be found to be anti-competitive and illegal under competition law. These contracts are void and no longer enforceable. It is under these circumstances that the welfare objectives of competition law and contract law may come into conflict, especially if the judiciary focus on the ex post distribution of gains from the contract in assessing its efficiency. As Michael Trebilcock has noted:

In emphasising these ex post allocations of gains and losses to parties immediately implicated in the contractual relationship, the judicial process tends to become preoccupied with short-run distributive justice issues as between these parties and to discount long-run efficiency implications of given decisions for the welfare of these classes of parties in the future. ${ }^{4}$

Ibid, p. 81.

Trebilcock, M. J. (1986) The Common Law of Restraint of Trade: A Legal and Economic Analysis, Carswell Company, Toronto, p. 403. 


\section{Theory and History of Contract Enforceability 5}

Contract law as it is known in developed economies has taken many centuries to evolve. The path is suggested in an interesting series of papers that imply that this evolution is inextricably bound to institutions that have unfolded with social and political change. They focus on emergent institutions that stimulated commercial economic growth in the $11^{\text {th }}-12^{\text {th }}$ centuries (see e.g., Lopez (1976)). ${ }^{6}$ Greif (1993) ${ }^{7}$ describes trading a institution of the $11^{\text {th }}$ and $12^{\text {th }}$ centuries that had its antecedent in the migration of a Jewish sect that ultimately spread around and beyond the North Africa and the Mediterranean becoming known as the Maghribi Traders. Based on records of the time and insights from repeated games, he argues that the Traders enjoyed rents from lowered transactions costs brought about by communication and a multilateral enforcement mechanism. Utilising the approach, Milgrom, North, and Weingast (1990) ${ }^{8}$ reason that the merchant courts at the champagne fairs of the $12^{\text {th }}$ and $13^{\text {th }}$ centuries was an institution that provided good incentives for gathering information, honouring agreements, reporting disputes and adhering to judgements that supported impersonal exchange relationships over time. The power of the state to advance or retard trade by its ambivalent position on commitment and enforcement led to other institutions of trade that enabled a better level of transactions across geographic and jurisdictional boundaries. Greif, Milgrom and Weingast (1994) ${ }^{9}$ argue that the formation of merchant guilds (e.g. the Hanseatic league) enabled efficient trade. These, and studies cited below, imply that institutions evolved with social and political change, and that trade requires such institutions for it to attain its efficient level.

This section relies heavily on Anderson, James, E. and Leslie Young, Imperfect Contract Enforcement, mimeo, Economics Department Boston College, 2001.

Lopez, Robert, S., “The Trade of Medieval Europe in the South”, in M.M. Postan and E. Miller, eds. The Cambridge Economic History of Europe, Vol. 2, New York, Cambridge University Press, 1976.

Greif, Avner, "Contract Enforceability and Economic Institutions in Early Trade: The Maghribi Traders' Coalition”, The American Economic Review, 83(3), 1993, 525-548.

Milgrom, Paul, North, Douglass, C., and Barry R., Weingast,” The Role of Institutions in the Revival of Trade: The Medieval Law Merchant, Private Judges, and the Champagne Fairs, Economics and Politics, 1, 1990, 1-23.

Greif, Avner, Co-odination, Commitment, and Enforcement: the Case of the Merchant Guild”, The Journal of Political Economy, 102(4), 1994, 745-776. 
The role of competition law in economies as they develop their contract-enforcement institutions has not, to our knowledge, been the subject of formal analysis. Although there were rules that governed traders behaviour - e.g. the reported, but unrecorded, Merchant Law of the Maghribi Traders - it is most unlikely that the practices that they governed had to do with market power: the prime focus of competition law. It is noteworthy that the very institutions that facilitated transactions and trade before the rule-of-law institutions of state were developed would be constrained by modern competition law. These institutions had to be monopolistic because they were addressing an externality, and the time and sustainability of their reputations that were critical to their function took time and sunk investment to render credible. There may have been some scale economies in operation as well. The monopolistic elements, of necessity, evolved to include sanctioned trade practices and information exchange that modern competition law seeks to regulate. For example, in the 1930s trade association membership in the UK entailed being party to a contract that typically promulgated a range of trade practices. The associations enforced such practices as minimum retail price by sanctions that included fines for breach. Many of these practices are per se offences under modern competition law. Furthermore, there is now very limited ability to induce contract enforcement by penalties under the rule of law, even if they are written into the contract. ${ }^{10}$

The development of the rule of law operated by the state has crowded and forced out earlier contract enforcement institutions. While contract enforcement is strengthened through the state institution of the rule of law, this institution also provides a credible way of regulating general commerce by means of competition law. Through both the actions of statutorially-based regulatory watchdogs and parties seeking to modify contracts, contractual uncertainty is enhanced by competition law. 
From an alternative perspective, consider that fact that it is normally argued that economically efficient trade requires reliable enforcement of exchange agreements, opinion surveys of traders reveal that contract enforceability varies widely across countries and that this results in less trade. ${ }^{11}$ Given this result, why do countries not develop institutions that facilitate contract enforcement and thereby enhance trade and its concomitant benefits? There are various potential explanations. They include the social power structure of economies where a ruling elite benefits from a quiescent judiciary. This explanation is not entirely satisfactory in an open economy: since the ruling elite would benefit from the taxes and business opportunities that trade would bring. A competing explanation is lack of institutional functionality represented by an absence of skills, organisational frameworks and professional norms and ethos. Neither is this possible explanation entirely satisfactory. Many less developed countries operate free trade zones that are likely to be extendable to international trade more generally. Finally, there may also be incentives for traders to prefer less than perfect contract enforcement.

Andersen and Young (2000) examine the implications of different institutional stages of development and the incentives for these to evolve over time. They consider the entire set of traders differentiated by their exposure to contract breach and their bargaining strength when breach occurs. Traders incur ex ante costs of exchange and agreements reached before these costs are incurred would be upheld by the rule of law. Absent the rule of law, traders that had incurred costs would be "held up" as the other party sought better terms. In an anarchic situation - defined as one where prior agreements cannot be enforced and agreements are settled on the balance of power to compel - suppose a seller can force very advantageous terms in dealing with a buyer. In this situation, few buyers would incur trading costs and contemplate the transaction, more sellers would be attracted to the transactions and hence the probability of a seller and buyer matching is lower than it would be if hold-up were not so likely. In short, by entry to the market in anticipation of favourable terms of exchange the favourable terms of exchange are dissipated by the lower probability of transactions. The welfare of all sellers may be improved by binding all parties to 
agreements under a "rule of law" that impartially enforces agreements and thereby reduces hold-up. ${ }^{12}$

Anderson and Young (2000) speculate that within geographically and politically fragmented Europe early development of the rule of law, largely independent of the power structure, facilitated inter-country trade in a way that was not necessary in China which, although geographically diverse, had a unified, jurisdiction. Foreign trade being of negligible importance, order in China was obtained by means of an efficient extensive bureaucracy. As China has sought in the last 20 years to foster international commerce there have been significant attempts to institute the rule of law.

The public institutions and social mores required for the rule of law took a long time to develop in Europe. In the interim a variety of institutions evolved to enable transactions within and across jurisdictions. These included monopolistic trading organizations that included guilds and associations. 13 They were necessarily monopolistic in that they were facilitating trade by internalising the negative externality that attended individual pursuit of hold up under anarchy, and having long term identity, interests and reputation that enabled them to credibly commit to not holding up individual traders no matter their jurisdiction origin. Anderson and Young point out that the sunk costs - including investment in reputation -of setting up such a monopoly had this effect. Government sanction provided commitment at a lower cost in some circumstances. However, the existence of monopolistic traders may inhibit the development of the rule of law in order to preserve their monopoly rents. ${ }^{14}$ They suggest that while a trading coalition may dispel hold-up issues by supporting the

Anderson and Young derive a condition that ensures this outcome. The condition relates to the costs and benefits of trade and elasticities relating to traders and price margins. They argue that the condition is quite general and admits the possibility that it is in the interest of the social elite and that may be driven by the demand for trade with foreigners. times see Grief, Avner, Milgrom, Paul, and Barry Weingast, Coordination, Commitment and Enforcement: the Case of the Merchant Guild”, Journal of Political Economy, 102(4), 1994, 745-776. Discussion Paper, 409, 2000 (as reported by Andersen and Young 2000 op cit) finding of strong negative correlations between the share of the fifteen largest families in market capitalisation and indices of judicial efficiency and the rule of law in modern East Asian countries suggests that this is a serious problem.. 
formation of a countervailing coalition ${ }^{15}$, that the rule of law can be obstructed by vested interests when each side of the market is dominated by a trading coalition. ${ }^{16}$

In a second paper Andersen and Young (2001) argue the rule of law may not always be in the individual traders' short-term interest and that this may inhibit the development of requisite institutions. The core element to this story is the general equilibrium interaction of contract breachers and their victims ex ante and ex post of the event. Their building block is traders that negotiate contracts before incurring the sunk cost of entry. After this cost is paid shocks affects traders' outside options. An ex ante desirable contract may, ex post be undesirable. Contracts will be enforced with some probability - changes to which represent changes to contract enforcement. The victims and defaulters may both turn to a spot market in which case their sunk costs remain sunk and are irrelevant to the result of bilateral bargaining. Because not all traders transact in the contract or spot markets there is a transactions inefficiency.

Traders on the excess side of the transaction may impose an externality on the other by reducing the probability of matching, as described in AY. An increase in enforcement increases this probability by attracting more scarce-side traders but at the cost of the expected return to excess side traders, as it impedes their ability to repudiate trades after a bad draw. Andersen and Young (2001) find that there are stable and unstable equilibria and that the effect of changes in enforcement depends on the distribution of shocks. An increase in enforcement can, in equilibrium, increase the rate of contract breach. The fewer contracts honoured can hurt traders on both the excess and scare sides of the transaction. Their model implies that for excess-side traders

(i) complete execution is worse than a set of high but incomplete levels of execution, and/or

(ii) no execution is better than a set of low levels of incomplete execution, even though, the Netherlands. Tracy $(1991,19)$ (Tracy James D. “Introduction” in James D. Tracy, ed. The Political Economy of Merchant Empires, Cambridge, Cambridge University Press, 1991.) reports that they frequently sought exclusive trading agreements with local princes who were given some military power. Andersen and Young op cit also argue that bilateral arrangements cut down on search costs. 
(iii) complete execution is better than zero execution and between these two situations, the profits of an excess side monopsonist (monopolist) would fall as the price falls (rises)

They argue that where buyers or sellers could veto changes in enforcement, as in international trade, they may do so. In countries such as China, India and Russia that appear to have the institutional functionality to enforce contracts may be choose not to. As (i)-(ii) suggest, small improvements in enforcement for a low-enforcement economy may lead it to be worse off than no improvement, although large improvements propounded by international agencies may leave it better off. The analysis is also applicable to domestic markets where traders on the predominant side of the market have the greater individual bargaining power and dictate institutional development. They suggest that China's modernisation has been driven by international trade yet unreliable contract enforcement has been a standard complaint of its trading partners. It may be that China's WTO membership represents a commitment to improve contract enforcement to a significant extent.

This section has examined the basis for strengthened contract enforcement and it has done so without invoking the cost-benefit calculus that might attend enforcement appraisal. It would be unusual in economics if the polar outcome of perfect enforcement were to maximise welfare when costs are considered. Nevertheless in the models considered, a very high level of consistent enforcement is welfare enhancing.

\section{Contracts, Spot Markets and Vertical Integration}

Firms can choose to organise themselves vertically using a variety of mechanisms. These can be thought of as existing along a continuum. At one end are simple spot market transactions. Moving along the continuum, the transactions may still occur through a market, but the governing contracts may be longer-term and involve various restraints on the actions of the parties to the contract. At the other end of the spectrum, transactions may be arranged within the firm - in other words, the firm may vertically integrate - either backwards (to include suppliers) or forwards (to include customers). The choice of whether or not to establish a vertical relationship 
"externally” through markets or "internally” within the firm is a cost-benefit judgment facing each firm depending on its particular market circumstances.

In the tradition of Coase, the most influential explanation of the choice of integration instrument is that it is driven by a desire to minimise the transactions costs associated with controlling principal-agent problems. ${ }^{17}$ Whether the firm chooses spot markets, long-term contracts or vertical integration will depend on the relative costs and benefits of each option. They are substitutes - but not always perfect substitutes. A firm will choose the vertical control instrument that delivers the highest net benefit. ${ }^{18}$

For example, the service quality of a retail firm might affect the demand for an upstream firm's products. The upstream firm accordingly has an incentive to control the downstream firm's quality decisions. The simplest way to do this may be to specify the level of quality in a contract. However, because quality may be difficult to observe, verify and specify in a contract, it may be void for uncertainty, or even if enforceable, not particularly effective at motivating the downstream firm. Vertical integration might "internalise" this externality and prove the cheapest way to overcome the problem. In other cases, the use of vertical restraints (e.g. tying arrangements, exclusive dealing, exclusive territories, resale price maintenance, etc.) written into contracts may prove the best way to "incentivise" the downstream "agent” to operate in the best interests of the upstream "principal”. principal). If the incentives of the agent are not (perfectly) aligned with those of the principal, and if the principal cannot perfectly monitor the agent, the opportunity arises for the agent to behave in a manner that may be counter to the interests of the principal. The term moral hazard is used in economics to describe the resulting form of opportunism. More recently, see for example: Perry, M. K. (1989) "Vertical Integration: Determinants and Effects", in R. Schmalensee and R. D. Willig (Eds) Handbook of Industrial Organization, Volume I, Elsevier Science Publishers; and Tirole, J. (1988) The Theory of Industrial Organization, MIT Press. 
A related explanation for the use of contracts is the potential for asset-specific "holdup”. This occurs where goods or investments are highly specialised to a particular task or relationship between two or more firms. ${ }^{19}$ Examples might include a gas pipeline being built from a particular gas field to supply a retail network in a particular town, or the purchase of specific container cranes by a port to service certain types of ships.

After the investment has been made, and (due to its specificity) largely sunk, one party to the transaction may behave opportunistically ex post (e.g. hold up by threatening not to use the infrastructure or seeking to do so at a price lower than agreed before it was built). Mitigating this risk through spot markets, or short-term arrangements, is very difficult, or at best, costly. Vertical integration may prove the most efficient means of overcoming opportunism and the risk of hold-up in such circumstances.

Long-term contracts that are struck ex ante can mitigate hold-up and spread the risks and benefits of the specific investment between buyers and sellers, provided they are enforceable. In effect, contracts assign "property rights" over the benefits and costs of the venture before investments are made and costs are sunk. If long-term contracts cannot be struck, or are unenforceable, such investments may not take place and a particular market may not come into being. As Goolsby (200) has pointed out, the welfare cost of foregone investment can be very high as it can result in a "missing market” in which the total of producer and consumer surplus is foregone. ${ }^{20}$

We will explain further in Section 5 below how long-term contracts can help protect relationship-specific assets from opportunistic behaviour, and encourage investment in high-risk projects and network industries.

\section{Competition Law, Contracts and Vertical Restraints}

While entering into contracts can be efficient and deliver improvements in social term Contracts: A Law and Economics Perspective”, New Zealand Law Review, Pt IV, pp. 423-458. 
welfare, contracts can also be entered into for anti-competitive purposes. In particular, long-term contracts can be used as a barrier to entry by foreclosing the opportunity for new entrants to get access to customers or to key inputs.

Perhaps the best way to think about this is to consider a monopolist producer of an (upstream) intermediate good. This good is combined with other inputs (e.g. sales assistance, advertising, a shop front, etc.) downstream by a number of retail firms for ultimate sale to the public. The downstream market is competitive.

In this situation, Aghion and Bolton (1987) have shown that the adoption of exclusive dealing contracts between the upstream monopolist and downstream retailers will be rational and raise entry barriers. Where a retailer breaks the contract by dealing with a new entrant, they are liable to pay liquidated damages to the monopolist. Liquidated damages clauses raise the costs of entry. This is because a new entrant looking to gain a foothold in the intermediate goods market will need to sign-up a good number of the retailers presently contracted to the monopolist. To do this, the new entrant will need to offer to pay the damages owed to the monopolist by each of the retailers that breach their exclusive dealing contract by dealing with the new entrant. This increases the cost of entering the market - a sort of "entry fee" related to the level of liquidated damages. ${ }^{21}$

While these contracts may be "privately" optimal for the incumbent monopolist and individual retailers, they are "socially" sub-optimal. It is also collectively sub-optimal for the retailers taken as a whole, but this externality is not factored into the decisions of the individual retailers. Welfare costs of exclusive contracts are imposed in terms of higher prices, or diminished service and quality, by preventing entry of new players altogether or by delaying it (until the contracts expire). Imposing legal barriers to entry through foreclosure may harm the level of dynamic efficiency and innovation, reducing social welfare over time. 
A recent paper by Mathewson and Winter (1997) has shown that, under certain conditions, the use of tying arrangements by an upstream monopolist can achieve a similar result to the use of exclusive contracts. This occurs where the tying is for the purchase of a given patented (monopolistic) good across two time periods (i.e. the period under patent and the period after expiry). This drives the choice of contract length toward longer-term contracts covering both periods, so as to foreclose entry of any new (competitive) players in the post-patent period. ${ }^{22}$

The above suggests that competition law has a legitimate role in curtailing certain types of anti-competitive contracts (especially exclusive arrangements) and vertical restraints between wholesalers and retailers. However, it is important to remember that contracts and other vertical arrangements can deliver efficiency benefits to society as well as competition detriment. Even contracts that harm competition may be welfare enhancing overall if the efficiency gains achieved are outweigh the competitive harm. The policy implications are ambiguous. ${ }^{23}$

The various ways in which contracts are treated under competition law (and by antitrust authorities) can have profound ramifications for the choice of integration instrument employed by firms. As we noted earlier, these can encompass spot markets, contracts or vertical integration.

The asymmetry imposed on the managerial decisions of firms by antirust legislation can be modelled using the same example of an upstream intermediate-product monopolist and a competitively structured downstream retail market. In addition, think of three forward integration strategies available to the monopolist, which, under certain assumptions, will have the same efficiency enhancing effects in downstream markets:

1. Using markets with tying arrangements (to control the downstream production mix);

See Mathewson, F. and Winter, R. (1997) “Tying as a response to demand uncertainty”, RAND Journal of Economics, Vol. 28, p. 577.

A formal treatment of the ambiguous welfare implications arising from the phenomenon of exclusive dealing has recently been provided by Bernheim, D. B. and Whinston, M.D. (1998) "Exclusive Dealing”, Journal of Political Economy, Vol. 106, pp. 64-103. They conclude that even where the use of exclusive dealing contracts is anticompetitive, a ban on exclusive dealing practices may have negative welfare consequences because it may encourage more inefficient forms of exclusion that are less explicit. 
2. Integrating forward by acquiring the downstream retailers; and

3. Integrating forward by organic (internal) expansion.

Efficiency may not be enhanced in competition law biases firms in favour of vertical integration by restricting the enforceability of vertical contractual arrangements on the basis of concerns about their anti-competitive effects.

\section{Long-Term Contracts, Specific Investments and Authorisation}

Goddard (1997) considers three key reasons why firms might want to enter into “long-term” contractual relationships:

- To achieve a reduction of contracting costs;

- To achieve the efficient allocation of risk over time; and

- Where there is a need to make specialised investments in order to be in a position to perform under the contract. ${ }^{24}$

The first rationale is straightforward. It is self-evident that entering into a single longterm contract will reduce the transaction costs from re-negotiating and entering into a multitude of shorter contracts. The risk allocation function of long-term contracts is common to the rationale for entering into shorter-term contracts. However, risk allocation through contract over a longer period may pose additional complexity in terms of the incentives to breach the contract and in the application of competition law. As noted above, highly specific investments raise major principal-agent problems that long-term contracts can help to alleviate. In this section, we focus on the second and third rationales for long-term contracts, namely, risk allocation over a significant time period and the case of specialised investments.

Long-term contracts may be adopted purely for the purpose of allocating specific risks to those parties that are in a better position to bear that particular risk. For example, under energy supply contracts the energy producer may agree to lock in the price of the output for the duration of the contract, while the buyer may agree to 
acquire their total fuel requirements or some specified minimum quantities from that supplier (e.g. as in "take or pay" clauses). ${ }^{25}$ This type of contract may also be used in the supply of highly-specialised inputs, where both the seller and buyer are exposed to opportunistic behaviour. ${ }^{26}$ Long-term contracts are also common in network industries where ownership of essential infrastructure (upstream) may be in the hands of a vertically-integrated incumbent. New entrants seeking to gain access to the network in order to compete against the incumbent (in downstream markets) may prefer to enter into longer term contracts in order to provide greater certainty for their entry decision.

In the case of specialised investments, a party to a trade may be required to make a large, specialised (and largely sunk) investment ${ }^{27}$ in order to be in a position to perform under a contract. The cost of that investment will need to be recouped over a long time horizon in the context of a specific trade relationship with the other party to the contract. Following the making of such a specific investment, and in the absence of a long-term contract, the other party to the trade relationship may refuse to pay the initially agreed price or to meet other conditions upon which the investment was undertaken (e.g. the level of use or minimum purchase requirements). As noted above, this behaviour is known in the economics literature as asset-specific "hold-up".

As an example, imagine that a port company is required to invest in specialised infrastructure in order to handle the goods of a specific exporter or importer. Following the port company making the specific and sunk investment (and in the absence of a long-term contract), the exporter/importer, knowing that the asset is specific, may refuse to pay the previously agreed price, insisting on a lower charge, applying a take-it-or-leave-it approach. As a consequence, the port owner would then

Carlton, D. and Goddard, D. (2002) "Contracts that lessen competition - what is section 27 for, and how has it been used?”, Working Paper, p. 19. that are the subject of the contract, and where the investment is sunk, in terms of being largely unrecoverable. 
need to incur additional transaction costs in pursuing litigation based on estoppel or in renegotiating the terms of use of the infrastructure. ${ }^{28}$

Where the investment involved is considerable and the asset specific ${ }^{29}$, a long-term contracting arrangement may be required ex ante in order for the investing party (i.e. the port company) to be certain to recoup the total cost of the investment over time, and therefore to commit to the investment. Were a shorter contract to be used, the opportunity for hold-up by the exporter/importer would again arise at the expiration of the initial contract. Provided they are enforceable ex post, the use of long-term contracts (or vertical integration) limits this type of opportunism, spreading the risks associated with investment in specific assets, and promoting economic efficiency.

The above example demonstrates that there are various efficiency-enhancing reasons for parties to enter into long-term contracts. However, due to their nature in restricting the freedom of parties to differing degrees, certain clauses in these contracts will, by necessity, restrict competition. ${ }^{30}$ Long-term contracts can be potentially more problematic than short-term contracts under competition law due to their long-term nature, restricting the economic freedom of the parties for significant periods. Tonkin (1998) states “... it is the element of exclusivity over a term which raises substantive issues of competitive concern, not least because supply and demand may vary during the term of the contract, and may not be predictable.”31

In addition to raising competition policy concerns, a longer term in a contract may also increase the incentives for a disadvantaged party to seek to set aside the contract

Estoppel is a legal principle that applies in contract law to prevent a party from denying that a contract actually exists, even where, according to the rules of contract, one does not technically exist. A party will be estopped from denying that a contract exists where they have made statements/representations as to the fact that a contract does or will exist, and, as a result, induce the other party to change their position (e.g. make a significant investment in specific infrastructure) on the faith of that representation.

According to Williamson, O. (1983) "Credible Commitments: Using Hostages to Support Exchange”, American Economic Review, Vol. 73, pp. 519-540, there are four types of asset specificity: site specificity, physical asset specificity, human asset specificity, and dedicated assets.

See Tonking, A. I. (1998), "Long-term Contracts: When Are They Anti-competitive”, Competition and Consumer Law Journal, Vol.6, p. 23.

Ibid, p. 15. 
ex post. These are expected to increase with the length of term, as the magnitude of losses suffered from honouring the contract are larger. ${ }^{32}$

Evans and Quigley (2000) describe the detrimental effects associated with the ability of a contracted party to challenge the validity of a long-term contract under New Zealand's competition law, stating that such opportunistic behaviour results in an increase in the costs of signing long-term contracts, possibly resulting in parties being unwilling to sign efficient long-term contractual agreements. It may also result in a shortening of the length of contracts below that which is optimal (reducing the incentive for a party to challenge the contract under competition law), and possibly reduce the extent to which a party invests in information relating to the contract, resulting in less efficient contracts which are more likely to be challenged. The overall consequence is likely to be a reduction in dynamic efficiency by reducing the level of certainty required for investment in specific assets, and a reduction in the overall gains from trade between erstwhile contracting parties.

Australian and New Zealand competition law can easily catch welfare enhancing contracts, undermining the certainty associated with long-term contracting. In New Zealand, challenges under competition law to the enforceability of contracts can come under two main sections of the competition legislation - the Commerce Act 1986 (Competition Act). These are section 27 (anticompetitive agreements) and section 36 (misuse of unilateral market power): especially under effects tests. ${ }^{33}$ However, the authorisation provisions (Part V of the Competition Act) are available to provide $e x$ ante clearance of potentially anti-competitive long-term contracts provided they have offsetting "public" benefits. The problem is that in both Australia and New Zealand, the authorisation provisions have at times come into play once contracts have been under way for a considerable period of time, and then it is very hard to say ex post whether the length of the contract and restrictive (and potentially anti-competitive) clauses are justified/appropriate in terms of the public interest. 
We now look at two New Zealand cases where the validity of long-term contracts has been challenged on anti-competitive grounds. The cases deal with two different types of long-contracts, namely, long-term contracts entered into where specialised investment is required for a party to be in a position to perform the contract (in the case of gas field exploitation) and where long-term contracting facilitates access to essential infrastructure (in the case of telecommunications).

\section{New Zealand Examples}

The following cases concern the gas and telecommunications industries where considerable investment in long-term production infrastructure is extremely important. In the Kapuni case a long-term contract was entered into in order to allocate the risk involved in making considerable specialised infrastructure investment. In the case of Telecom/Clear, a long-term contract was entered into in order for a competitor to gain access to an essential infrastructure facility. In both cases, the validity of the long-term contract was challenged during the term of the contract.

\subsection{Kapuni}

The Kapuni gas case concerned the enforceability of a long-term (exclusive) requirements contract for the supply of gas. The exclusive supply contact was entered into due to the need for the parties to make specialised investment in gas production infrastructure prior to the performance of the supply contract. Under the contract, the owner of the gas field agreed to supply all of the gas produced from the field to one party to the exclusion of all others. The court recognised the benefits from these types of long-term contracts:

'Output' and 'Requirements' contracts are recognised as having various benefits for new entrants to a market where large capital investments are required as well as existing participants in a market where economies of scale may result from such contracts. ...However, the exclusive dealing characteristics of such arrangements may run foul of competition laws. ${ }^{34}$ 
The validity of the contract was challenged by the owner of the gas field, under sections 27 and 36 of the Commerce Act, more than 20 years after the contract was entered into. Their concerns related to the combined effect of two long-term contracts that tied up the entire supply from the only two significant gas fields in New Zealand to specific parties, where two related companies were parties to each contract.

Specifically, the exclusive buyer at the Kapuni field, Kapuni Gas Contracts Ltd, was wholly owned by a company that held a significant interest (33\%) in NGC, a company entitled to residual supply from the Maui field. ${ }^{35}$ The Kapuni agreements were entered into before the Maui agreements. The gas field owner claimed that the existence of the Kapuni long-term contract in combination with the Maui long-term contracts was in breach of the Competition Act because it conferred market power upon NGC in the wholesale and retail reticulated gas markets, substantially lessening competition in these markets.

The court found that the combined effect of the Kapuni and Maui contracts was to substantially lessen competition in the reticulated gas market in breach of section 27 of the Act. In making its finding, the court stated:

Here we have a long-term contract in a wholesale market, effectively totally foreclosed to competition, which contract has run for 29 years. We are asked by the defendants to find that, because it concerns a dedicated field, we should not strike it down, even though it might run for another 20 years ...We do not believe that the exploration and efficiency arguments are sufficient to overcome the foreclosure of competition which arises from the [buyer's] unconstrained market power. ${ }^{36}$

The New Zealand High Court did explicitly take into account the economic benefits of the long-term supply contract in terms of its impact on "exploration and efficiency”, in assessing whether a breach had occurred, weighing it against the anticompetitive detriment. The court had accepted expert evidence to the effect that gas exploration would be adversely affected if long-term contracts could be held to be

The exclusive buyer under the Kapuni contract, Kapuni Gas Contracts Ltd (KGCL), was wholly owned by Fletcher Challenge Ltd, which owned 33\% of the shares of NGC. KGCL had an agreement to on-sell the gas to various petrochemical companies and NGC, which was entitled to all gas produced not consumed by the petrochemical companies. The gas produced at the Maui field was dedicated to three parties under a long-term contract, one of which was NGC. 
unenforceable ex post. ${ }^{37}$ Further, the court hypothesised that had it been asked at an earlier stage to authorise the contract that it may have done so. However, the court opted for a highly interventionist remedy, varying the Kapuni gas contract to release half of the total gas production of the field to a competing party.

\subsection{Telecom New Zealand v Clear}

This case concerned a long-term contract entered into between the owner of the telecommunications network infrastructure in New Zealand, Telecom Corporation of New Zealand ("Telecom”) and a new entrant to the industry, Clear Telecommunications Ltd (“Clear”). ${ }^{38}$

Clear sought access to Telecom's network in order to compete with Telecom for the provision of certain telecommunications services. Following a long running dispute between the parties about the terms on which Clear could have access to part of Telecom's network, an interconnection fee agreement was reached. Under the agreed pricing regime, Clear would pay no access fee to Telecom for use of the network but would pay a constant per minute charge for network usage. The usage charge would remain constant throughout the five-year term of the contract. Subsequent to entering into the contract, Telecom expanded its offering of a new off-peak charging regime for services to households, a service for which Clear was competing. The adoption of this regime made it difficult for Clear to match Telecom's prices for this service. Clear attempted to renegotiate the pricing terms with Telecom, who refused. Clear reacted by refusing to pay Telecom the agreed interconnection fee under the longterm contract, and resorting to the Competition Act in seeking to have the contract overturned. ${ }^{39}$

In challenging the enforceability of the contract under competition law, Clear alleged that Telecom held a position of dominance in the market for interconnection services,

Ibid.

This is a high-level summary based on the review of the case in Evans and Quigley, op cit.

As per Dammery, R. (1999) "Section 46 of the Trade Practices Act: The Need for Prospective Certainty", Competition and Consumer Law Journal, Vol. 6, pp. 246-257, "the courts in New Zealand have taken the view that pending a decision on the substantive question of legality under the Commerce Act, a contract provision that is plausibly claimed to be in breach of the Act, even by a party to the contract, cannot be enforced." (Cited from Evans and Quigley, op cit, p. 79). This may increase the incentives of a party to a contract to challenge its validity under competition laws, especially in the cases concerning withholding of payments under a contract. 
and that its charges under the Interconnection Agreement had the effect of diminishing competition and were a breach of sections 27 and 36 of the Commerce Act .40

Telecom attempted to have the claims struck out on the grounds that the parties had contracted out of the Commerce Act in settling their interconnection disputes within a private contract. The High Court held that it was not possible to contract out of the Commerce Act making it clear that private contracts cannot take precedence over the application of competition laws. ${ }^{41}$

By entering into an interconnection agreement with no connection fee and a fixed usage charge, Clear avoided the risk associated with obtaining a certain level of scale, ${ }^{42}$ but accepted the risks associated with its inability to obtain volume discounts and to differentiate pricing between peak and off-peak calls. Clear exposed itself to the risk that Telecom might adopt a pricing strategy that made the volume-based interconnection fee disadvantageous, but we must assume that it did so having calculated the costs and benefits associated with different strategies in contract negotiation..$^{43}$

We have therefore argued that one interpretation of Clear's strategy was that they accepted an interconnection contract that minimised their exposure to a lump sum access payment on the assumption that they would be able to challenge the contract under competition law if competition in the market evolved in a way that made the contract disadvantageous to them. The fact that the entrant (Clear) has the option to appeal to competition law, but that the incumbent in the market does not, is an illustration of the asymmetric effects of competition law. These effects may have implications both for the price at which the incumbent is prepared to enter such contracts and for the efficiency of the contracting process more generally. This unreported).

High Court, CL 20/97, 18 July 1997, unreported. 
dispute thus illustrates the way in which competition law may undermine the enforceability and efficiency of contracting.

\section{Conclusion - striking the appropriate balance between contract and competition law}

Given the need to strike some balance between certainty in contracting (through the proper enforcement of binding contracts), and the role of competition laws (in striking down agreements which harm competition), there is a potential for conflict in terms of maximising social welfare. Since it is not open to contracting parties to opt out of the application of competition law, there is no obvious mechanism by which contracting parties can avoid the costs that result from uncertainty about the enforceability of contracts. Precedents in New Zealand mean that there is some degree of uncertainty for parties as to the ultimate enforceability of the contract going forward. As the case studies in Section 6 suggest, New Zealand's competition law can easily catch welfare enhancing contracts (Kapuni). In addition, parties to a contract may seek to use competition law in an opportunistic or strategic way once a contract is in place (Telecom/Clear).

In our view, the right balance between contract and competition law is yet to be reached.

What is required is some means to increase the degree of certainty in the future enforcement of contracts, particularly long-term contracts where the contract has been entered into in order to provide assurances surrounding a specific investment. An ex ante clearance approach similar to that currently applied to mergers is one possible approach. ${ }^{44}$ This process should not just be open to contracts which yield "public" benefits, as per the present authorisation procedures, but it should also apply to contracts where the benefits are largely "private" but the various clauses of the contract may be open to challenge on competition grounds.

Further, with or without an ex ante clearance process, the courts should be very reluctant to set aside long-term contracts which have been in place for a considerable

On the elements of such an ex ante approach, see Tonking, op cit, pp. 27-30; and Evans and Quigley, op cit, pp. 92-93. 
period of time. This is especially true where the basis for doing so rests on changed circumstances that were unforeseen at the time of the original contracting process, or opportunistic behaviour of one of the parties to the contract. Such intervention imposes significant external costs on the economy, and is inconsistent with economic efficiency. Large investment projects often require enforceable contracts; perceptions of enforceability are harmed by contracts being overturned or stuck down. Such decisions undermine contract law and put investment and efficiency at risk.

In our view the implications of this analysis for developing countries is that their first priority should be in promoting mechanisms that will reduce uncertainty about the enforceability of contracts. We have shown that historically in Western societies mechanisms that were important in promoting contractual enforcement would be illegal under modern competition law. This suggests, equally, that a balance between the evolution of Western-style competition law and a tolerance of traditional institutions that may promote contractual enforcement will be part of an efficient reform path for developing economies. Competition law should have a lower priority, both because of the ambiguous welfare implications of aspects of competition law and because of its intolerance of institutions which reduce competition in some dimensions but have a net positive impact on economic welfare because they promote the enforceability of contracts. 